\title{
Articles
}

\section{The Legislation Critical Concept of Goods-in-law under Scrutiny}

\author{
Claus Roxin ${ }^{1}$
}

\section{Introduction}

For almost ten years, the question of whether it is possible to curtail the state's penal powers by restricting them to the violation or endangerment of goods-in-law (Rechtsgüter) has been the subject of lively discussion again in Germany. ${ }^{2}$ Hefendehl $^{3}$ has traced the newest developments until 2006. The debate then gained even greater importance due to the German Federal Constitutional Court's ${ }^{4}$ (Bundesverfassungsgericht) 2008 decision that no limits to the legislator's penal competences could be derived from the goods-in-law principle. In $2010^{5}$, I then responded in a detailed statement "On the more recent development of the goods-in-law debate" ("Zur neueren Entwicklung der Rechtsgutsdebatte") and insisted on the legislation critical function of the goods-in-law approach.

Abroad, too, the question of whether the tasks of criminal law can be determined by way of protection of goods-in-law is met with much interest and controversial echo. Thus, for instance, Bacigalupo ${ }^{6}$ writes that "the concept of goods-in-law is given a decisive legitimating function" in Italy and Spain. This is confirmed by the fact that in the commemorative volumes dedicated to me in 2011, Romano ${ }^{7}$, PolainoNavarrete ${ }^{8}$ and Gimbernat ${ }^{9}$ considered the function of the good-in-law in criminal law. Also in Greece, the question is much discussed. While Androulakis ${ }^{10}$ denies that the protective goods-in-law principle has any restrictive effect on penalisation,

\footnotetext{
${ }^{1}$ Prof. Dr. Dr. h. c. mult. Claus Roxin, Professor Emeritus Ludwig-Maximilians-University Munich. Translation by Research Assistant Carl Robert Whittaker, B. A. (Oxon.), Ludwig-Maximilians-University (Munich).

2 An important trigger for this was a 2002 conference on "Die Rechtsgutstheorie" (The Theory of Goods-in-Law), whose reports and discussions were published in 2003 by Hefendehl/von Hirsch/Wohlers in an anthology. In 2007, an extended edition of the anthology was also published in Spain. The discussion was continued in 2004. The reports and discussions of the follow-up conference were published in 2006 by von Hirsch/Seelmann/Wohlers under the title "Mediating Principles. Begrenzungsprinzipien bei der Strafbegründung".

${ }^{3}$ Hefendehl, Goltdammer's Archiv für Strafrecht (= GA), 2007, 1 et seq.

${ }^{4}$ Entscheidungen des Bundesverfassungsgerichts (= BVerfGE) 120, 224 et seq.

${ }^{5}$ Roxin, Festschrift (= FS) Hassemer, p. 573 et seq.

${ }^{6}$ Bacigalupo, FS Jakobs, 2007, p. 1 et seq.

${ }^{7}$ Romano, ScientiaUniversalis, FS Roxin, 2011, p. 155 et seq.

${ }^{8}$ PolainoNavarrete, as fn. 6, p. 169 et seq.

${ }_{9}^{9}$ Gimbernat, Festgabe für Claus Roxin zum 80. Geburtstag, GA, 2011, p. 284 et seq.

${ }^{10}$ Androulakis, FS Hassemer, 2010, p. 271 et seq. with reference to Manoledakis as a "disciple of the allegedly critically functioning concept of goods-in-law" (272, fn. 3).
} 
Kaiafa-Gbandi ${ }^{11}$ considers that: "The teachings of the German criminal law jurisprudence on the good-in-law as a material element which not only establishes criminalisation but chiefly limits it, represents ... one of its most important bequests for the European legal culture."

Of course, the goods-in-law concept plays no role e. g. in France and America. But the American criminal law scholar Dubber" at least emphasises that it "were to be welcomed if doctrine, legislation and legal practice in the United States would refer to a systematically uniform concept of goods-in-law." Also, the "harm principle"13 as developed in Anglo-American criminal law - i. e. the restriction of criminal law sanctions to harmful behaviour - is related to the principle of protection of goods-in-law.

The currency of the topic and the still persisting extraordinary controversy of all related questions justify another return to the problem of goods-in-law. Of course, I do not wish to repeat my earlier remarks and therefore am essentially limiting myself to engaging with suggestions and criticism of primarily the newest literature which provoke a statement.

In doing so, I tackle four questions:

1. Does criminal law have any protective function (of goods-in-law), or should it only confirm the validity of norms?

2. How can one, if one considers the purpose of criminal law to be the protection of goods-in-law, define the concept of the good-in-law so that it yields concrete results?

3. Is the doctrine of goods-in-law refuted by the necessity of behavioural offences (offences protecting emotions)?

4. Does the postulation that criminal law should restrict itself to the protection of goods-in-law have significance only for criminal policy, or does the constitutionality and thus the legal validity of a criminal provision depend on it at least in some cases?

\section{Is the purpose of criminal law the protection of goods-in-law or the confirmation of the validity of norms?}

The first precondition for a recognition of the limiting function of the notion of goods-in-law is of course the recognition of protection of goods-in-law as a purpose of criminal law. This premise already is not undisputed. Jakobs ${ }^{14}$ and his followers hold the view that the criminal law does not protect goods-in-law but the validity of the norm. The criminal significance of, e. g., a manslaughter allegedly is "not the

\footnotetext{
${ }^{11}$ Kaiafa-Gbandi, in Eser/Hassemer/Burkhardt (Eds.), Die deutsche Strafrechtswissenschaft vor der Jahrtausendwende, 2000, p. 261 et seq. (263).

${ }^{12}$ Dubber, Zeitschrift für die gesamte Strafrechtswissenschaft (= ZStW) 117 (2005), 485 et seq. (516/517).

${ }^{13}$ Further Roxin, Strafrecht, Allgemeiner Teil, $4^{\text {th }}$ Ed. 2006, $\$ 2$ para. 123 et seq.

${ }^{14}$ I referonlytotheessaybyJakobs in the FS Saito, 2003, p. 780 et seq, entitled "Was schützt das Strafrecht: Rechtsgüter oder Normgeltung?". A discussion of this and further references from Jakobs' works are found in my essay in GA 2011, 678 et seq. (688-692).
} 
violation of victim's flesh or the eradication of his consciousness, but the deed's implicit and objectifiable claim that body and consciousness ... need not be respected ... By this claim, the norm ... is denied. Crime thus is the disavowal of the norm." 15 Accordingly, it is not that which we call the good-in-law: the life as empirical given fact, but only the prohibition of killing (the validity of the norm) which is protected. "The deed is damage to norm validity; the punishment is its removal."16

This is however based on an exaggerated normativism. Certainly the punishment contributes to the stabilisation of norms; even if - contrary to Jakobs - this is not its sole purpose. But the stabilisation of norms is no end in itself and instead is supposed to contribute to the prevention of future real individual or societal harm (i.e. violations of goods-in-law). It thus ultimately serves the protection of goods-in-law and would be pointless without this purpose.

A similar criticism of the conception by Jakobs has been raised by Spanish authors as well. Thus Mir Puig ${ }^{17}$ writes: "While the criminal policy concept of goods-in-law makes the legitimacy of a criminal norm dependent on its serving the purpose of protecting values that are worthy of protection, the view of Jakobs in a way reverses this approach and turns the norm into a per se legitimate object of criminal protection: no longer the instrument which has to be legitimised by its purpose, the norm turns into its self-legitimising purpose." He rightly criticises that thereby the restrictive effect of the notion of protecting goods-in-law is lost.

Similarly, an author as close to Jakobs as PolainoNavarrete ${ }^{18}$ argues in the same vein when he says: "The criminal law protects goods-in-law to prevent violations of the same goods, whereby it confirms the authority of the norm as a component of the social structure." "The norm aims ... not to protect itself, but the goods and values it contains." 19

Jakobs, while not abandoning it expressis verbis, has under the pressure of criticism effectively retreated from his thesis that punishment exclusively serves the confirmation of the norm. He now emphasises ${ }^{20}$ that confirmation of norms, if norms are to "guide behaviour" ("verhaltensleitend"), has to be "cognitively underpinned" ("kognitiv unterfangen" $)^{21}$ and elaborates this abstract statement with the example that nobody would "during a nightly stroll through the city park ... comfort himself with the fact that he must not be robbed or even slain, much rather he would, if he takes the stroll, also assume that most probably he will not be mistreated in such

\footnotetext{
${ }^{15}$ Jakobs, as fn. 13, p. 765/764 (Japanese reverse numbering).

${ }_{16}$ Jakobs, as fn. 13 , p. 762.

${ }^{17}$ Mir Puig, GA 2003, 803 et seq. (866).

${ }^{18}$ Polaino Navarrete, as fn. 6, p. 176.

${ }^{19}$ Polaino Navarrete, as fn. 6, p. 181; Scheinfeld, as fn. 6, p. 183 et seq. (187) also reaches the result: "A criminal goodin-law of norm protection is ... not to be recognized."

${ }^{20}$ Jakobs, since the work ,Staatliche Strafe, Bedeutung und Zweck“, 2004.

${ }^{21}$ Jakobs, as fn. 19 , p. 29.
} 
ways." But this means: The criminal law must, to guide behaviour, follow the purpose of preventing real violations of goods-in-law.

With that, one will be able to put ad acta the objection derived from the norm confirming effect of punishment against the criminal law's purpose to protect goods-in-law.

\section{Is a practically effective legislation critical concept of goods-in-law possible?}

\section{The circumscription of a legislation critical concept of goods-in-law}

My textbook ${ }^{22}$ states on this matter: "The purpose of the criminal law is to secure for its citizens a free and peaceful coexistence while warranting all constitutionally guaranteed basic rights. If one refers to this purpose summarily as protection of goodsin-law, then goods-in-law are to be understood as all circumstances and purposes which are necessary for the free development of the individual, the realisation of his basic rights and the functioning of a governmental system that is based on this vision."

Since a long time, such a concept - notwithstanding some distinctions - has had notable proponents, to which I can only refer in general terms here. ${ }^{23}$ However, it has also again in recent years found decided advocates, of whom I want to name in particular Schünemann ${ }^{24}$, Steinberg ${ }^{25}$, M. Heinrich ${ }^{26}$, Frister $^{27}$ and Kaspar ${ }^{28}$, to whose advanced thoughts I will return.

The decisive, freedom preserving conclusion of such a goods-in-law doctrine is that criminal provisions are illegitimate if they encompass a behaviour which does not impair either the free development of the individual nor its societal preconditions (e.g. an intact judiciary and state administration). In this vein also Frister ${ }^{29}$ says: $^{2}$ "Both individual goods-in-law as well as the public goods-in-law ultimately serve the individual's opportunities for development." The difference, he says, merely is that the violation of an individual good-in-law directly impairs the opportunities for development of a particular human being, while the violation of a public goodin-law indirectly impairs the opportunities for development of all human beings. Frister, too, concludes ${ }^{30}$ that the legislature's scope of action is limited insofar as "a behaviour that in no way impairs other persons' opportunities for development may not be deemed to be a criminal injustice".

\footnotetext{
${ }^{22}$ Roxin, as fn. 12, § 2 para. 7 .

${ }^{23}$ References in my text book, as fn. $12, \S 2$ para. 7,8 , note $21,22$.

${ }^{24}$ Schünemann, Mediating Principles, as fn. 1, p. 18 et seq.

25 Steinberg, FS Rüping, 2008, p. 91 et seq.

${ }^{26}$ M. Heinrich, as fn. 6, p. 131 et seq.

${ }^{27}$ Frister, Strafrecht, Allgemeiner Teil, $5^{\text {th }}$ Ed. 2011, Ch.3, para. 21, 29 et seq.

${ }^{28}$ Kaspar in his yet to be published habilitation treatise "Verhältnismäßigkeit und Grundrechtsschutz im Präventionsstrafrecht", 2011.

${ }^{29}$ Frister, as fn. 26, para. 21.

${ }^{30}$ Frister, as fn. 26, para.32.
} 


\section{Is such a concept of goods-in-law too vague to allow for a limitation of criminal law?}

One of the most common objections against a legislation critical concept of goods-in-law suggests that the latter is too vague and therefore lacks effect. Thus Dubber $^{31}$, after examining several controversial offences, reaches the result that "Roxin's ... theory of goods-in-law" proves "at the end of the day rather toothless." Even in 2011, Stuckenberg ${ }^{32}$ writes: "The topos "protection of goods-in-law" admittedly pursues the undisputedly desirable aim of a rational criminal policy and a liberal and humane criminal law, but it is no scientific concept with analytical potency, to the contrary, rather an instrument to obfuscate the underlying, occasionally diffuse and more emotionally perceived rather than precisely determined values." In response to this and similar criticisms, four points are to be made:

\section{a) The importance of the goods-in-law concept for the resolution of current legal problems}

The thesis that the goods-in-law concept does not have any material practical significance is mistaken. I wish to clarify this in six examples in which the legislature or a constitutional court (not just that of Germany!) had to deal with the permissibility of criminal punishment, and of which five still today are in the focal point of the discussion.

The oldest matter of dispute concerns the criminal liability for homosexual behaviour of adults. It was penalised in Germany until 1969, the Government Draft 1962, which was to prepare a new criminal code, intended to retain the criminal liability, and our constitutional court had confirmed the constitutionality of the criminal liability. ${ }^{33}$ But it is evident that such behaviour, if it takes place consensually within the private sphere, does not impair anybody's freedom of development and does not in any way disturb the free coexistence of human beings. A legislation critical concept of goods-in-law thus leads to the postulate of the impunity of consensual homosexual acts of adults.

The German legislature followed ${ }^{34}$ the reform movement which had been supported by the authors of the alternative drafts and repealed the criminal provision in 1969. Critics admittedly claim that this was not due to the recognition of a legislation critical concept of goods-in-law but on a general shift in views on the propriety of punishment of homosexuality. Based on his personal view - he lived in Germany at the time - Gimbernat ${ }^{35}$ has rightly disputed this. If the views have shifted today, then that is the result and not the precondition of the reform policies of the time. Furthermore, one has to appreciate that views on the propriety of

\footnotetext{
${ }^{31}$ Dubber, as fn. 11,510 .

32 Stuckenberg, GA 2011, 653 et seq. (657).

${ }_{33}$ BVerfGE 6, 389 et seq.

${ }^{34}$ Here, particularly the Alternativ-Entwurf Sexualdelikte, 1968, was influencial.

${ }^{35}$ Gimbernet, as fn. 8, 286.
} 
punishment can only change relatively quickly where the threat of punishment is based not on a good-in-law that is to be protected but by a mere moral stance. Concerning offences against body and life, concerning deprivations of liberty, or theft, a shift in views leading to impunity would be inconceivable because these are based on goods-in-law whose protection is indispensable for the society.

A second example is criminal liability of possession of drugs for personal use, ${ }^{36}$ regarding which similarly any impairment of others is lacking and whose impunity therefore is generally demanded by proponents of a legislation critical concept of goods-in-law. Our constitutional courts had to consider this question ${ }^{37}$ as well and upheld criminal liability with the proviso that it ordered punishment to be refrained from in minor cases. This is a step in the right direction but creates legal uncertainty which could have been avoided if the provision had been declared invalid. By contrast, on 25 August 2009, the Argentinian constitutional court has declared the criminal ban of drug possession for personal consumption to be unconstitutional. $^{38}$

A third case which also has been dealt with by the constitutional court concerns organ donations among the living. Under German transplantation law, ${ }^{39}$ they are only permitted to the benefit of related or closely associated persons. Thus those who altruistically - in most cases even anonymously - wish to save another human life by donating a kidney are not allowed to do so. The doctor who harvests an organ in violation of this prohibition faces criminal liability. ${ }^{40}$ Since here, too, any impairment of others is lacking and organ donation even serves particularly charitable purposes, the criminal liability here too lacks the legitimation of protecting goods-in-law.

Nonetheless, our constitutional court ${ }^{41}$ has declared this provision to be permissible. Accepting that self-harm is an "exercise of basic rights freedom", it argued that still "it is a legitimate public welfare concern to protect human beings from inflicting a greater personal harm upon themselves."

In the application to the concrete case, this however is mistaken in two ways. On the one hand, nobody will want to represent the view that the state may penalise an unhealthy lifestyle. And on the other hand, an organ donation, if performed after careful medical examination and consultation, does not entail a "greater personal harm". The life expectancy of a human with just one kidney is not lower than the population average. The constitutional court's decision therefore has been largely rejected and may perhaps lead to a change in law.

The fourth and of late most discussed constellation in which the concept of a legislation critical goods-in-law concept is the focus of dispute is incest among

\footnotetext{
36 § 29 s. 1 Narcotics Law (Betäubungsmittelgesetz, BtMG).

${ }^{37}$ BVerfGE 90,145 et seq.

${ }^{38}$ On this Greco, in Hefendehl, Grenzenlose Vorverlagerung des Strafrechts?, 2010, p. 73 et seq.

${ }^{39} \S 37$ s. $1,2^{\text {nd }}$ sentence Transplantationsgesetz (=TPG).

${ }^{40} \S 19$ s. 1 TPG.

${ }^{41}$ Neue juristische Wochenschrift (= NJW), 1999, 3399 et seq. In detail Roxin, in: Häberle (Ed.), 60 Jahre deutsches Grundgesetz, 2011, p. 65 et seq. (72 et seq.).
} 
siblings. This is penalised under German law. ${ }^{42}$ Here, too, if the siblings act without duress, consensually and with unrestricted responsibility, any impairment of personal development is lacking so that the principle of protection of goods-in-law demands impunity.

In 2008, our constitutional court has by contrast judged the penal provision to be "reconcilable with the Grundgesetz" - the German constitution. ${ }^{43}$ In doing so, for the first time it took a position on the criminal liability limiting function of the principle of protecting goods-in-law and expressed the view that the legislature's powers could not "by reference to ... goods-in-law be constricted" 44 . Requirements regarding the aims of a criminal norm could "not be derived from the criminal law doctrine of goods-in-law." 45 In a curious self-contradiction to this, the court then nonetheless tries to locate certain goods-in-law - the family, sexual self-determination, hereditary health - that are protected by the criminal provision. As the reasons can easily be refuted, the decision has met general disapproval. $^{46}$

A fifth and, if viewed in respect of protection of goods-in-law, highly explosive problem is the denial of historic facts which in certain cases is penalised in some states (for instance the denial of the Holocaust or other genocides). $\S 130$ s. 3 of the German StGBimposes criminal liability for the denial and trivialisation of acts of genocide that were perpetrated during the time of National Socialism, if this takes place publicly or at an assembly and in a way which is capable of disturbing public peace. A framework decision of the European Union from $2007^{47}$ demands a penalisation of public acceptance, denial or gross trivialisation of genocide, crimes against humanity and war crimes.

By contrast, on 7 November 2007, the Spanish constitutional court has declared the criminal liability for the denial of genocide to be unconstitutional. ${ }^{48}$ Similarly, the punishment of the denial of a genocide which, in the view of the French legislature, had been committed between 1915 and 1917 by the Turks against the Armenians has been declared unconstitutional on 28 February of this year by the constitutional assembly, the country's highest constitutional committee, by reason of violation of freedom of speech and impermissible interference with the work of historical science.

In view of the legislation critical principle of protection of goods-in-law, the punishment of acceptance of such acts is indeed legitimate. For they threaten the safety of parts of the population still living among us today which had been affected by those acts. In Germany, this case can however already be punished pursuant to $\S 130$ s. 1 StGB as inciting hatred against parts of the population.

\footnotetext{
$42 \S 173$ s. $2,2^{\text {nd }}$ sentence StGB.

${ }^{43}$ BVerfGE 120, 224 et seq.

${ }^{44}$ BVerfGE 120, 242.

45 BVerfGE 120, 242.

${ }^{46}$ A detailed discussion is provided by my contribution in the journal „Strafverteidiger“ (= StV), 2009, 544 et seq.

${ }^{47} C f$. on this $M . K r a u \beta$ in the "Leipziger Kommentar" (= LK), 12 $2^{\text {th }}$ Ed. 2009, $§ 130$ para. 25.

${ }^{48}$ For details Gimbernat, as fn. 8, 292 et seq.
} 
To the extent that, in contrast, a dispute over historic facts takes place without agitation or discrimination, one rather will have to deny a violation of goods-inlaw. ${ }^{49}$ For the freedom of speech also captures the pronouncement of aberrant opinions. To the extent that such cases are historically disputed, they have to be settled by historical science and not the criminal law. In contrast, to the extent that they - like the National Socialist violent crimes - are proven, it is in the interest of a society's climate of opinion to refute such insinuations publicly and emphatically rather than to punish Holocaust deniers and trivialisers and thereby allow them to act as martyrs or to claim that the state supresses historical debates with the assistance of criminal law.

As a last provision lacking a good-in-law, I wish to present the offence of youth pornography ( $\$ 184$ c StGB), which has been inserted into the German criminal code in 2008 pursuant to a framework decision by the European Union. ${ }^{50}$ I limit myself to sec. 4 of this provision. According to it, criminal liability applies to "whoever undertakes to obtain possession of youth pornographic writings which reproduce an actual event, or who possesses such writings". Because pursuant to $\S 11$ s. 3 StGB, pictures are equivalent to writings, an 18-year old is therefore punishable if, with her consent, he carries a sexually explicit picture of his 17-years old girlfriend. ${ }^{51}$ Since sexual relations between both are legally permitted, it is not apparent why she should not permit her boyfriend said intimate portrait or even present him with one. Manfred Heinrich" ${ }^{52}$ rightly calls this "in view of protection of goods-in-law simply unacceptable".

The outlined examples, which could easily be expanded on, in my view show without doubt that Dubber errs when he says: ${ }^{53}$ "The offences which fail Roxin's goods-in-law test are either exotic or obsolete." All mentioned problems are by contrast to this assertion the subject of lively discussion and have with the exception of the last even been dealt with by constitutional courts of various countries; regarding my example from the area of youth pornography, the absence of court decisions is supposedly due to the fact that the provision has not been in force for long yet. Also, only one of the mentioned offences is "obsolete" insofar as criminal liability for homosexual behaviour by adults has been abolished. But of course it is not an objection to a legislation critical concept of goods-in-law that in this case it has prevailed in the legislature.

\section{b) The necessary abstraction of highest legal principles}

The objection of excessive vagueness of a legislation critical concept of goods-inlaw secondly must be met with the response that highest legal principles do not let themselves be captured by a definition that is susceptible to subsumption but merely

\footnotetext{
${ }^{49}$ In moredetail Kühl, in Bernsheim/Ulsenheimer (Eds.), Bochumer Beiträge zu aktuellen Strafrechtsthemen, 2003, p. 103 et seq.

${ }^{50}$ For details on the five section provision Manfred Heinrich, as fn. 6, p. 135 et seq.

${ }^{51}$ Fr.-Chr. Schroeder, GA 2009, 217.

${ }^{52}$ M. Heinrich, as fn. 6, p. 135.

${ }^{53}$ Dubber, as fn. 11, 508.
} 
indicate a guiding standard that must be developed concretely by application to legal subject-matter. It is merely this standard which my above-given (III, 1 at the beginning) circumscription of the good-in-law seeks to specify, and it has already proven useful in the necessarily compact analysis of my six examples.

For concrete solutions, one has to resort to the "Drei-Stufen-Schema des Rechtsgüterschutzes" ("Three-tier schema of protection of goods-in-law") recently developed by Manfred Heinrich" ${ }^{54}$, according to which every criminal provision of doubtful legitimacy must be examined as to what is to be protected, who is to be protected, and what it purports to protect against. Only at the end of this analysis it becomes apparent whether the criminalised behaviour impairs the free development of the individual or its societal preconditions.

The concretisation of the goods-in-law principle is moreover assisted by the nine guidelines that I have drafted which can prove helpful in this process. ${ }^{55}$ I cannot elaborate on them here, but at least can list them as keywords: arbitrary, purely ideologically motivated criminal laws or those that violate basic rights do not protect goods-in-law; immoral or reprehensible behaviour does not as such amount to a violation of goods-in-law; the violation of one's own human dignity is not a violation of goods-in-law; the protection of feelings can be acknowledged as protection of goods-in-law only in the case of fear due to realistic threats; conscious self-harm, its enabling or support do not violate goods-in-law (of others); predominantly symbolic criminal provisions have no function of protecting goods-in-law; taboos are not goods-in-law; protected goods of unseizable abstraction cannot be acknowledged as goods-in-law. Regarding collective goods-in-law, Greco ${ }^{56}$ has recently presented a sensible concept according to which it is not permitted to "postulate a collective good-in-law as the protected good of a particular provision if the impairment of this good-in-law always simultaneously requires the impairment of an individual good-in-law".

I think that on the basis of such specifications, the concept of goods-in-law can indeed by helpful in the determination of the legitimacy of criminal provisions. In respect of the concept of goods-in-law, Mir Puig ${ }^{57}$ has rightly said: "In fact, all general principles require concretisation through public debate. Principles such as those of democracy or equality are so general that they permit wholly different concretisations, but no reasonable person draws from this the conclusion that it is preferable not to rely on such principles."

\section{c) The recognition of a legislation critical scope of action does not devalue the concept of goods-in-law}

The remark by Mir Puig indicates what critics of the concept of goods-in-law often overlook: namely that that which is to be classified as a good-in-law has no

\footnotetext{
${ }^{54}$ M. Heinrich, as fn. 6, p. 148.

${ }^{55}$ Roxin, as fn. 12, § 2 para. 13-49.

${ }^{56}$ Greco, as fn. 6, p. 199 et seq. (213).

${ }^{57}$ Mir Puig, as fn. 16, 866.
} 
absolutely accurate, "clear-cut" boundaries, but that a provision's link to goods-inlaw may be more or less pronounced. Where it is detectable at all, the legislative scope of action covers penalisation just as much as the creation of a misdemeanour or the waiver of any sanction whatsoever. I wish to emphasise this by some examples which I borrow from the newest literature.

Thus e.g. Romano ${ }^{58}$, dealing with my concept, takes the view that the legislature should remain within the confines of a "goods-in-law oriented criminal policy", and that a criminal provision is impermissible if it protects "in reality nothing at all". But he considers it indeed acceptable ${ }^{59}$ for the legislature to introduce a "helmet duty for motorcyclists and belt duty for car drivers" and imposes for their violation "a monetary penalty or fine" even though this primarily protects the driver himself. "The decisive rejection of forms of legal paternalism that are moderate and not uncommon in Anglo-Saxon legal systems to me seems indefensible."

In the result I do agree with Romano, but believe that the legitimacy of a belt or helmet duty reinforced by sanctions can be explained not by reference to the selfendangerment of the driver but to the likely harm to others. I however doubt whether the social costs for "medical treatment of hospital stays" mentioned by Romano are sufficient for this. For if the injured person pays these costs himself, the reason drops away. Further, these costs are in most cases covered by health or accident insurance. Also, presumably no legislature will get the idea to penalise an unhealthy lifestyle or the engagement in dangerous sports by reason of the costs potentially so caused.

But since a driver who does not wear a seat belt loses control of his vehicle more easily and one who does and can thus cause third-party damage, a duty to wear seat belts is justified. This applies even to passengers if, without a belt, they may be ejected from the vehicle and thereby cause damage. Further, unbelted passengers in cars as well as cyclists and motorcyclists without a helmet create the danger that other actors may be punished for negligent homicide or causing grave bodily harm, while no or only slight bodily harm would have been caused if a helmet or seat belt had been worn. Already the prevention of the liability of third parties has the character of preserving freedom and thus goods-in-law; they are thus protected from impairments that result from the carelessness of others.

Accordingly, the legislative intervention here still is within the confines of protection of goods-in-law. Since of course due to the paternalistic component the protection of goods-in-law is less pronounced than in "pure" offences protecting goods-in-law, as a matter of criminal policy it is preferable to treat such behaviour as a misdemeanour. But it is also within the legislative discretion to provide for a limited monetary penalty or to waive a sanctioning regulation altogether. Thus in Germany, no helmet duty for cyclists has been introduced so far.

\footnotetext{
${ }^{58}$ Romano, as fn. 6, p. 168.

${ }^{59}$ Romano, as fn. 6, p. 164.
} 
Similar points apply to the case of Holocaust denial as discussed above. Romano says: "Here, too, it is my view that it is inappropriate to attempt to resolve the problem of negationism with the help of a criminal norm." But he considers it acceptable "if the forbidden behaviours (acceptance, denial or trivialisation of the crimes of the Holocaust) were only punishable in the case that they take place in circumstances that temporally and locally concretely threaten public peace."

I consider this to be correct, but in such cases there is also a clear endangerment of goods-in-law. I have only demanded" impunity for the "mere denial without agitational character" and declared a punishment to be appropriate if somebody for instance "accepts these murders or ... claims they had been invented by the Jews to draw contempt on the Germans". This kind of agitation threatens the freedom and security of the Jews living in Germany; and it seems that it is such cases that also Romano wishes to capture. Thus in this case, too, a legislation critical goods-in-law approach seems to me in no way misplaced, but instead is what enables the drawing of appropriate distinctions.

This should be elaborated further by a third example: the possession of child pornographic writings or pictures, which is subject to punishment pursuant to $\S 184$ b s. $42^{\text {nd }}$ sentence of the German StGB. "The reason for the penalisation is hard to discern", it is stated in a leading commentary. ${ }^{62}$ The prevention of a potential passing on is not a sufficient reason. For the recipient is not harmed, and the serious child abuse that is involved in the production of such material has already happened.

One can however - other than in the above mentioned case of youth pornography - establish a link to goods-in-law that legitimises the penalisation if one assumes that the provision is supposed to prevent the promotion of child pornography production and the child abuse it involves. Following up on Fr-Chr. Schroeder ${ }^{63}$, I have elaborated on this elsewhere ${ }^{64}$ and can only refer to the basic thought that the demand for child pornography can be reduced by penalising obtaining it. Here this is - by contrast to the comparator case of drug possession - sensible because the producers do not act in unseizable international networks but, as Schroeder lays out, predominantly operate as private "small businessmen" and thus are dependent on customers who are willing to obtain it. But in any event: It is within the confines of the legislature's scope of action to pursue this kind of intention to protect goods-inlaw with the help of the criminal law.

\footnotetext{
${ }^{60}$ Romano as fn. 6, p. 165.

${ }^{61}$ Roxin, as fn. 12, § 2 para. 41.

62 Schönke/Schröder/Perron/Eisele, StGB, $28^{\text {th }}$ Ed 2010, § 189 b para. 15.

${ }^{63}$ Fr.-Chr. Schroeder, ZRP 1990, 299; NJW 1993, 2581; FS Kaczmarek, 2006, p. 570.

${ }^{64}$ Roxin, Libro en homenaje a Eberhard Struensee, Buenos Aires, 2011, p. 505 et seq. (527 et seq.). The discussion has only been published in Spanish.
} 


\section{d) The principle of subsidiarity as an indispensable complement of the notion of protection of goods-in-law}

Finally it must be considered that the necessity of a violation or endangerment of goods-in-law is by no means the only principle for limiting criminalisation. As also the civil law, the public law and especially the misdemeanours law protect goods-inlaw, in the face of an infringement of a good-in-law there still is the question whether that infringement ought to be prevented by criminal law or other legal regulations (e.g. damages, permission requirements or control measures).

Predominantly, it is assumed that a threat of punishment as the most invasive sanction may only be considered if milder regulations do not suffice. The thereby characterised principle of subsidiarity as a maxim for limiting criminalisation is of wholly equal rank to the principle of protection of goods-in-law. One can therefore describe the purpose of the criminal law as "subsidiary protection of goods-in-law"65. It thus is no objection against the principle of protection of goods-in-law when Achenbach" recently emphasises with reference to "the supraindividual goods-in-law of economic criminal law" that the goods-in-law doctrine provides "no truly distinguishing criteria for legitimate and illegitimate offences". He himself refers to the task of the subsidiarity principle if he says: "The doctrine of the alternatives to the criminal law for me always was a central chapter of economic criminal law." 67

From this follows the demand for a "science of subsidiarity" to be developed independently beside the doctrine of goods-in-law. I have made this demand already some years ago ${ }^{68}$ and by this meant interdisciplinary and institutionalised research on the question of which regulatory mechanisms enable a publicly desired protection of goods-in-law in the most effective and simultaneously freedompreserving form possible.

This is a very complex and widely unexplored range of problems which cannot be dealt with any further here, but which always has to be kept in mind where legislative limitation of punishment is at issue.

Some central questions are particularly disputed. This for instance is true for Tiedemann's ${ }^{69}$ thesis that a threat of punishment under certain circumstances may be less repressive than a system of control that significantly restricts freedom. Urgently in need of discussion is also the thesis by Theile $e^{70}$ of a "claim to societal control by the criminal law" which in economic criminal law can lead to the creation of new goods-in-law protected by criminal law, ${ }^{71}$ while again others want to energetically push back the criminal law with the help of the principle of subsidiarity. Extensive

\footnotetext{
${ }^{65}$ Further Roxin, as fn. 12, § 2 para.97 et seq.

${ }_{66}$ Achenbach, StraFo 2011, 422 et seq. (425).

${ }^{67}$ Achenbach, as fn. 65, 426.

${ }^{68}$ Roxin, Schlussbericht zu Neumann/Prittwitz (Eds.), Kritik und Rechtfertigung des Strafrechts, 2005, p. 175 et seq. (183 et seq.).

${ }^{69}$ On this with further references now Trendelenburg, Ultima ratio?, 2011, p. 172-200.

${ }^{70}$ Theile, Wirtschaftskriminalität und Strafverfahren, 2009, p. 5 et seq.

${ }^{71}$ Critically regarding this Achenbach, as fn. 65, p. 426.
} 
"pre-studies on a future science of subsidiarity, exemplified in economic criminal law" have recently been presented by Trendelenburg ${ }^{72}$.

\section{Does the necessity of behavioural offences refute the basic notion of a legislation critical doctrine of goods-in-law?}

A counter movement derives the rejection of the goods-in-law theory not from its lack of suitability for clearly determinable limitations on criminal law, but rather from a conception for the legitimacy of threats of punishment that is different in principle. Its leading advocate in the more recent German discussion is Stratenwerth, ${ }^{73}$ according to whom "not the violation of particular goods-in-law, but solely the disrespect of behavioural norms that are fundamental for the basic consensus of a society" may be considered as reason for penalisation. ${ }^{74}$ According to this, penalisation is determined by $^{75}$ "the societally and legislatively recognised basic attitude to uphold a certain norm and on the other hand to simply not want a behaviour".

Against this, three objections must be raised. First, the fact that a majority of the population is unwilling to tolerate a behaviour to which it objects must not lead to the conclusion that the behaviour may also be punished if it does not impair anyone in their freedom of development. Wohlersasks, ${ }^{76}$ even though he himself tends to be critical of the goods-in-law doctrine, rightly, whether one can, "if one bids farewell to the "goods-in-law dogma", satisfy the claim" to "rationally explaincriminal norms?". And he rightly emphasises: "A7 "A conviction cannot, for the sole reason of its "being there", be recognised as worthy of protection." And Seelmann, too, determines: ${ }^{78}$ "Punishment ... is only ... necessary, where someone ... as perpetrator has reduced the legal status of another, the victim." Thus one can say: The punishment of consensual homosexual behaviour among adults was in opposition to the BVerfG - illegitimate even at a time at which the Government Draft 1962 " considered it an "in the general conviction disgraceful behaviour".

Second, in the absence of an impairment of a good-in-law,today it is no longer possible at all to determine a "basic consensus" in our multicultural society on the need for punishment of a particular behaviour. That is shown already by the six exemplary cases I have dealt with above (III, 2, a) in which admittedly the penalisation of behavioural offences without goods-in-law has been largely upheld by the legislature, but whose treatment is in all cases disputed to the extreme.

72 Trendelenburg, as fn. ,68.

73 Stratenwerth, in: Hefendehl/von Hirsch/Wohlers, as fn. 1, p. 255 et seq.

${ }^{74}$ According to the summary in Hefendehl, as fn. 1, p. 286.

75 Stratenwerth, asfn. 72 , p. 300.

76 Wohlers, FS Amelung, 2009, p. 129 et seq. (138).

77 Wohlers, as fn. 75, p. 137.

78 Seelmann, FS Jung, 2007, p. 897.

${ }^{79}$ Bundestags-Drucksache IV, 650, 376. 
Third, a "basic consensus" on penalisation of behaviour that does not impair goods-in-law is impossible from the outset also because the basic consensus in our society tends to strive towards that everyone may develop his personality according to his individual preferences so long as he does not impair the development of others or its legal preconditions. Wohlers ${ }^{80}$ has put this well: "In societies which are founded on the values of pluralism and normative individualism, the normative basic consensus strives ... towards that different conceptions of the good compete with each other on the market of opinions that is free from state influence, and that the state ought to restrict itself to providing the framework conditions within which this market can function."

The view of Stratenwerth has found a new proponent in Volk ${ }^{81}$, who adds to it a thought from the penal purpose doctrine. He relies on the penal purpose of positive general prevention and refers ${ }^{82}$ to the "trust effect" recorded by me which occurs "when the citizen sees that the law prevails", and to the "pacifying effect which occurs when the general rights awareness is due to the sanction calmed in view of the violation".

He concludes from this: "The purpose of criminal law is the protection of feelings. Trust, the satisfaction of rights awareness in turmoil ... are nothing other than feelings. This legal purpose doctrine does not without more fit with the doctrines on the good-in-law. Little concerns the people more than a violation of a taboo ..." He therefore wants ${ }^{83}$ - insofar somewhat different from Stratenwerth - not to abandon the concept of goods-in-law, but to broaden it and extend it to feelings.

He advocates that the concept of goods-in-law should be "opened" and that "also protecting taboos, ethically supported expectations, feelings" should be viewed as "a legitimate state task". Of course, he too wishes "not automatically" to demand criminal protection for such feelings. He merely wants to move the rationale for the legitimacy of criminal law intervention "to a different place, namely to proportionality or subsidiarity". "An advantage would not least be the harmonisation with the legal purpose doctrine, which aims at societal consciousness and ... wishes to reinforce "feelings"." Androulakis ${ }^{84}$ speaks in similar terms when advocating an "indignation principle".

Two arguments weigh against such reasoning.

First, it is not the purpose of positive general prevention to achieve an effect of trust and pacification in regard to any given feelings or expectations. The citizen should merely be allowed to trust that his safety and its institutional preconditions are warranted and that he may do everything which does not impair the freedom of development of others in an impermissible way. A criminal law protection of expectations and feelings going beyond that would also not create a pacifying effect,

\footnotetext{
${ }^{80}$ Wohlers, as fn. 75, p. 139.

${ }^{81}$ Volk, as fn. 6, p. 215 et seq.

82 Volk, as fn. 6, p. 220.

${ }^{83}$ Volk, as fn. 6, p. 224.

${ }^{84}$ Androulakis, as fn. 9, p. 279.
} 
because it would restrict the freedom of action of others and thus would evoke conflicts within society.

Second, a shift in rationale which refers not to the lack of an impairment of goods-in-law but to subsidiarity and proportionality would turn a clear criminal policy postulate ("behaviours that do not impair goods-in-law shall not be punishable") into cases of major uncertainty in decisions. For the questions of when criminal law protection of feelings, if permitted, is disproportionate and when, if applicable, it should be replaced by other legal regulations, or when protective measures can be waived altogetherwould be endlessly disputed.

Other authors, while professing the goods-in-law approach that excludes a general protection of feelings, wish to nonetheless recognise the latter in exceptional cases or in special cases that go beyond legitimate safety needs.

Thus Hefendehl, one of the most important proponents of the legislation critical principle of goods-in-law, ${ }^{85}$ wishes to exceptionally permit that the violation "of societally enrooted homogenous value and behavioural notions without a thereby caused harm" should be subject to punishment.

With this, it is admittedly possible to half-decently explain an offence such as animal cruelty, which has always been a problem for the goods-in-law doctrine. ${ }^{86}$ But Gimbernat" has rightly responded to Hefendehl, that then "also the criminal prohibition of homosexuality would be justified if in a society the predominant feeling existed that this behaviour is reprehensible". This objection is confirmed by Hefendehl himself when he justifies ${ }^{88}$ the decriminalisation of homosexuality by stating that it took place at a time at which in view of the rejection of that mode of behaviour there existed no "social dominance".

But the liberal function of the goods-in-law approach lies precisely in its protection of minorities against a dominating opinion of the majority. Furthermore, one should consider that the public opinion on tolerability or reprehensibility of behaviours that do not impair goods-in-law, namely in questions that relate to political, religious or sexual views, is wavering and susceptible to manipulation. No rational criminal law policy can be based on this.

A very original attempt of a distinguishing treatment of protection of feelings within the framework of the goods-in-law doctrine has recently been undertaken by Gimbernat. ${ }^{89} \mathrm{He}$ explicitly professes "the goods-in-law theory" and agrees in result with all the views I propose. But in some cases, he bases this on the assumption that "legitimate feelings" may be protected as goods-in-law.

Thus the "feeling of unease" ("Unwohlgefühl"), 90 which is caused by such animal cruelty as is penalised in Spain as well as in Germany, allegedly is a legitimate feeling so that the "general prohibition of cruelty against animals" is justified. Its legitimacy

${ }^{85}$ Hefendehl, as fn. 1, 2003, p. 128.

${ }^{86} \mathrm{Cf}$. on this further the following discussion of Gimbernat.

87 Gimbernat, as fn. 8, 289.

${ }^{88}$ Hefendehl, Kollektive Rechtsgüter im Strafrecht, 2002, p. 57.

${ }^{89}$ Gimbernat, as fn. 8, 284 et seq.

${ }^{90}$ Gimbernat, as fn. 8, 288/289. 
allegedly follows from the fact that a European Treaty dating from 1986 stipulates the duty "to respect and appropriately consider the capacity for suffering and remembering" of all vertebrates. ${ }^{91}$ From the German perspective, one may add that also Art. 20 a Grundgesetz (= GG) proclaims the protection of animals.

In the case of the criminal liability which both countries impose on the "disturbance of peace in death" (Störung der Totenruhe, $\S \S 167 \mathrm{a}, 168$ StGB), it allegedly is "the feeling of unease or the outrage which such desecration of graves cause that is the good-in-law protected by these offences" 92 . For the "respect for the dead" allegedly is a manifestation of the constitutionally protected "ideological or religious freedom (also of the atheist ideology)".

Finally, the duty to wear helmets and seat belts, which in Spain is subject to an administrative sanction, allegedly does not protect "the life and health of the norm violators, but instead the understandable and legitimate feeling which stirs the citizens when the number of traffic victims increases ..." $" 93$.

By contrast, e.g. the punishment of homosexuality, of blasphemy or the Auschwitzlüge is allegedly misplaced because the feelings of indignation raised by them are illegitimate. The reason for their illegitimacy allegedly is that these feelings are opposed by constitutionally recognised rights to sexual activity ${ }^{94}$ as well as the freedoms of expression and speech.

This is a highly interesting and in view of the reference to constitutionally value judgments also an approvable approach. But the question is whether truly "feelings" are the subject of protection.

The prohibition of animal cruelty thus does not primarily aim to spare our feelings, but to spare the animals from unnecessary suffering. ${ }^{95}$ All legal regulations for animal protection are based on the protection of the animals and not on the aim to save humans from agitation. If this were different, cruelty that takes place to the exclusion of the public and at which nobody takes offence should not in fact be penalised. As animals are protected by European treaties and German constitutional law, I have no concerns in considering their capacity to feel pain as a protected good-in-law. If we recognise the higher animals with which we can communicate and whose capacity to feel pain corresponds to ours as a part of our world that is worthy of protection, it is only consequent to classify their human inflicted suffering as a violation of a good-in-law. ${ }^{96}$

Of course, thereby a purely anthropocentric doctrine of goods-in-law is in narrow confines - for the protection of animals is minimal in relation to the protection that humans enjoy - extended to a "creatural" doctrine of goods-in-law, i. e. animals are protected as "fellow creatures". But the mentioned European and

\footnotetext{
${ }^{91}$ Gimbernat, as fn. 8, 289/290.

92 Gimbernat, as fn. 8, 289/290.

93 Gimbernat, as fn. 8, 292.

${ }^{94}$ Gimbernat, as fn. 8, 289.

${ }^{9}$ Cf. Greco, FS Amelung, 2009, p. 3 et seq. (15): „The animal cruelty offence protects ... the animal and not us.“

${ }^{96}$ Greco, as fn. 94 , refers to the fact that animals require protection due to their limited capacity for selfdetermination.
} 
constitutional standards justify this. Gimbernat ${ }^{97}$ rejects such a conception with the rationale that "the animals do not possess subjective rights". But an impairment of goods-in-law does not necessarily require the violation of subjective rights, as e.g. the environmental offences show.

One will also have to consider a respectful treatment of the deceased as part of a dignified human life in our society. A desecration of graves or insulting mischief with a corpse impairs the coexistence and the continuing right of personality of the deceased. The emotional reactions are only the reflex to these impairments. And regarding the duties to wear helmets and seat belts I have already attempted to lay out how real goods-in-law are protected here.

In my view, in the mentioned cases the legitimate feelings of indignation of third persons are not themselves the good-in-law, but rather the justified reaction to the violation of the latter.

\section{Good-in-law, criminal policy and constitution}

Even if one assumes - as I have attempted to expound - that a legislation critical doctrine of goods-in-law delivers sufficiently clear results, what remains an extremely disputed topic is which consequences follow from a penalisation of behaviours that do not impair goods-in-law. The proponents of the goods-in-law principle so far have not been able to clarify whether the postulate of the impairment of a good-in-law is a criminal policy guideline which is offered to the legislature but does not bind it, or whether and, if so, under which preconditions, the lack of a link to a good-in-law may lead to the invalidity of a criminal provision. That the second alternative is not absurd from the outset follows from the fact that constitutional courts in Germany, France, Spain and Argentina have dealt with such provisions and that the foreign tribunals have arrived at a declaration of invalidity in the cases I discussed.

\section{On the significance of the goods-in-law approach for criminal policy}

I have myself said ${ }^{98}$ and in this regard am in agreement with most proponents of the goods-in-law doctrine: 99 "The proponents of a legislation critical goods-in-law concept turn ... primarily to the legislature and erect criminal policy postulates without wanting to claim for their suggestions ... in all cases constitutionally binding force."

Such a significance for criminal policy of the goods-in-law doctrine is frequently also recognised by authors who strictly reject the binding force of its results on the legislature. Thus e. g. Dubber ${ }^{100}$ says, by supporting the reception of the concept of goods-in-law in North America: "Even if it turns out that the goods-in-law

\footnotetext{
${ }^{97}$ Gimbernat, as fn. 8, 289.

${ }^{98}$ Roxin, as fn. 4, p. 584 et seq.

${ }^{99}$ Cf. only my references to Schünemann and Sternberg-Lieben, as fn. 4, p. 585, comment 71, 72.

${ }^{100}$ Dubber, as fn. 11, 516.
} 
concept is not based in the constitution and thus in the modern democratic state under law has no destructive bite, it may still play a constructive role in a general theory of criminal law and furthermore function as an - albeit not binding guideline for the legislature and the courts."

One must not underestimate the criminal policy function of the goods-in-law doctrine. For if e. g. the German legislature since the reforms of 1969/1973 at least in tendency reduced the formerly so-called offences against public morality (Sittlichkeitsdelikte) to assaults "against sexual self-determination" ( $\$ 174$ et seq. StGB), then the legislation critical goods-in-law concept which was propagated by alternative drafts has played a significant role. Also regarding other disputed questions that were heard by the constitutional court (for instance regarding the drug or transplantation laws or incest among siblings), it could lend substantial assistance to the legislature.

\section{Protection of goods-in-law and constitution}

The further question whether a constitutional provision can be invalid if it does not protect a good-in-law is answered in very different ways. Thus still today it is not infrequent for any binding effect on the legislature to be denied. Bacigalupo ${ }^{101}$, for instance, considers the conclusions drawn by me from the goods-in-law principle for "correct viewed as legal policy". "But it is settled that no doctrine on the subject of protection of criminal law has at its disposal a criterion which determines the limits applying to the restriction by criminal law means of freedom in a society based on it." "The criminally protected goods-in-law are a creation of the legislature."

In similar terms, it was recently said by Stuckenberg: 103 "Insofar as one wants to prescribe for the legislature from an academic viewpoint which aims it should select and which not, then as a suggestion in the (criminal) political discourse, which ideally is driven by the persuasive power of the arguments, this is without more possible and necessary. But the notion that the legislature is legally bound, for instance to only penalise behaviour harming goods-in-law, is, if it cannot be converted into an imperative constitutional argument, which is not apparent, not reconcilable with the democratic legislature's freedom of action. As unpleasant as it may be, it will hardly be possible to give reasons for forbidding a parliamentary majority to penalise "merely immoral" behaviour."

This describes the salient point. For of course not professors' views but only the constitution can impose legally binding limits on the legislature. But the proponents of the goods-in-law doctrine have never claimed anything different. Thus e.g. in my works with reference to Stächeling and Hassemer, one can read: ${ }^{104}$ "The constitu-

\footnotetext{
${ }^{101}$ Bacigalupo, as fn. 5, 12.

${ }^{102}$ Bacigalupo, as fn. 5, 14.

103 Stuckenberg, GA 2011, 653 et seq. (658).

${ }^{104}$ Roxin, as fn. 5, p. 586 (references to Stächelin and Hassemer there comment 76, 77).
} 
tional connection for the impermissibility of such criminal provisions is the prohibition of excess which is derived from the principle of proportionality."

It is also not the case that one can replace the principle of protecting goods-inlaw with the principle of proportionality, as for instance Weigend ${ }^{105}$ envisages when he says that the good-in-law as a legislation critical concept is "inferior to the constitutionally supported topos of proportionality of state interference". They much rather complement each other, as is correctly explained in the commentary by Schönke/Schröder "106. "Regarding the question which purposes can be pursued with criminal legislation, the goods-in-law doctrine and constitutional requirements ... interlock; the principle of proportionality in turn presupposes a good that is to be protected for which the goods-in-law doctrine can provide indicators, although of course the result of the constitutional examination is not thereby predetermined." 107

Also Kasparin his fundamental monograph on the principle of proportionality ${ }^{108}$ arrives at the result that both approaches are to be combined. In doing so, he says, it would be possible to "also seamlessly include substantive requirements of the goodsin-law theory into the constitutional examination. At least such an understanding of the proportionality test escapes the objection not to provide any standards for the content of criminal laws".

A different conception actually is not possibleat all. For after all there is no proportionality as such, rather the criminal law interference must necessarily be put into relation with the aims so pursued. For this, type and extent of the protection of goods-in-law play an important role.

The necessity and possibility of the goods-in-law doctrine's linkage to the constitution can by now be considered as the dominant view. Thus Frister ${ }^{109}$ emphasises "that the concept of the good-in-law today also in criminal law sciences is defined coming from constitutional law ...". According to Steinberg ${ }^{110}$, today's proponents of a legislation critical goods-in-law doctrine are "largely in agreement on the aim ... not to establish or graft upon the constitution a concept foreign to it, but to concretise the expressions of the constitution itself in the criminal law area with the implementing aid of the goods-in-law concept."

Our constitutional court thus is right when it states ${ }^{111}$ that the legislature's scope of action could not be constricted by instances outside the legislation. "112 "It rather finds its limit - in the area of criminal law as elsewhere - only in the constitution itself ..." But the court errs if it believes that proponents of a legislation critical

\footnotetext{
105 Weigend, LK, $12^{\text {th }}$ Ed. 2007, Introduction para. 7. In this vein also Androulakis, as fn. 9, 277 et seq.

106 Schönke/Schröder/Lenckner/Eisele, StGB, $28^{\text {th }}$ Ed. 2010, para. 10 a before $\S 13$.

107 Similarly Greco, ZIS 2008, 238: „Basically, the proportionality test presupposes a doctrine of goods-in-law, for one needs a reference point for the evaluation of an interference as suitable, necessary and reasonable."

108 Kaspar, as fn. 27, p. 168.

109 Frister, as fn. 26, $3^{\text {rd }}$ chapter, para.32.

110 Steinberg, as fn. 24, p. 102.

111 BVerfGE 120, 242.

112 Cf. the quote above III, 2, a).
} 
goods-in-law doctrine support a different view. ${ }^{113}$ The goods-in-law doctrine can develop its criminal policy conceptions independently of the constitution and offer them to the legislature. But it of course can derive the invalidity of a provision only from a violation of the constitution.

The dispute accordingly culminates in the question whether and, if so, under which conditions a criminal provision that does not impair the opportunity for development of others and its institutional preconditions - i. e. that does not violate or threaten any goods-in-law - can be unconstitutional. For Stuckenberg, as shown above, a "binding constitutional argument ... is not apparent", and also our constitutional court opines ${ }^{114}$ that the goods-in-law doctrine provides "no substantive standards which necessarily would have to be adopted into the constitutional law...".

By contrast, the proponents quoted above refer the legislation critical goods-inlaw approach primarily to the principle of proportionality (suitability, necessity, reasonableness) of state intervention which is a fundamental principle of the rule of law. A legal provision that does not protect goods-in-law on this reasoning could as an unreasonable, excessive and thus disproportional interference in the citizen's freedom be unconstitutional. When this could be the case in individual instances is however hardly clarified. This is - as of yet - an undeniable weakness of a position which wishes to accord to the goods-in-law approach a constitutional significance going beyond its criminal policy function. Neumann ${ }^{115}$ therefore deserves full support when he says: "Necessary is however the development of differentiated patterns of reasoning which make the application of the principle of proportionality on concrete constellations possible."

One will not be able to say that any and all punishment of acts that do not violate goods-in-law violates the principle of proportionality and thus is unconstitutional. If e.g. someone "publicly performs sexual acts" and thereby causes an annoyance to others ( $\$ 183$ a StGB), he does not violate another's good-in-law; for no-one's opportunity for development is thereby impaired. Thus under criminal policy aspects, the treatment as a misdemeanour would be more appropriate. But a measured criminal punishment is not already unconstitutional. For one cannot deny the legislature the sanctioning of violations of public morals and decency if these take place in an offensive manner in the public. This view finds support in Art. 2 s. 1 GG, pursuant to which the free development of the personality may be restricted by the "law of public morals" ("Sittengesetz"). ${ }^{116}$ Similar points apply to the so-called confrontation protection ( $\$ 184$ s. 1 no. 6 $\mathrm{StGB}$ ) which subjects the unrequested sending of pornographic material to punishment.

\footnotetext{
${ }^{113}$ Similarly Frister, as fn. 26, $3^{\text {rd }}$ chapter, para. 32 .

114 BVerfGE 120, 242.

115 Neumann in: von Hirtsch/Seelmann/Wohlers, as fn. 1, p. 136.

116 Androulaki specifically refers - without reference to $§ 183$ a StGB - to this, as fn. 9, p. 274, 281, comment 36.
} 
By contrast to this, there are not few provisions in regard to which a balancing exercise leads to the result that an intervention with criminal punishment is disproportionate. This is true, against the $\mathrm{BVerfG}^{117}$, e.g. for the commercial presentation of pornographic films; for here, if the viewers have been informed of the nature of the film, no-one is against his will subjected to pornographic films. The protection of minors which the provision allegedly pursues can easily be achieved by way of identification checks. It is also disproportionate that $\S 184$ a StGBthreatens punishment for those who make bestiality pornographic writing or pictures available to others. For if an adult wishes to watch such things, nothing and nobody is harmed so that the threat of up to three years' punishment amounts to a clear violation of the proportionality principle, especially since not even the personal performance of sexual acts with animals is punishable. Neither can the "law of public morals" in either of the named cases be relied on for the proportionality of penalisation because pornography as such is allowed and nobody takes offence at the events. Similar points apply to the case discussed above that somebody has in his possession a sexually explicit photograph of his 17-year old girlfriend.

In my view, the prohibition and punishment of the altruistic organ donation among the living who are not related or closely associated (above III, 2, a, third case) is - restricted of course to the doctor performing the transplantation - also disproportionate and unconstitutional. For any interference with the personal freedom of development of those involved is lacking. The risks of potential involuntariness or organ trade can be ruled out in other ways. But then the prevention of a socially and ethically similarly valuable saving of life with the help of criminal law is out of all proportion to the aims pursued by the legislature.

It is not possible within this paper to examine all provisions for which a violation of a good-in-law is not apparent as to their constitutionality in view of the principle of proportionality. But the examples given may show that a detailed analysis of all relevant provisions can render rationally persuasive solutions and in some cases suggests the assumption of unconstitutionality. ${ }^{118}$

Further, insufficient attention is paid to the fact that the penalisation of behaviours that do not impair goods-in-law is also subject to other constitutional limits which, to the extent that they are withdrawn from all balancing exercises, bind the legislature even more strongly than the principle of proportionality. This particularly applies to interferences in the "core area of the private lifestyle" ("KernbereichprivaterLebensgestaltung") which the German constitutional court has derived from human dignity and declared untouchable. ${ }^{119}$ An interference by the legislature in this core area accordingly entails unconstitutionality.

\footnotetext{
117 BVerfGE 47, 109 et seq.

${ }^{118}$ Rich material for argument is offered by the monograph by Hörnle on "Grob anstößiges Verhalten", 2005, specifically on reason and limits of the $\$ \S 184,184 \mathrm{a}-\mathrm{d}$ StGB; Greco, in: Rechtswissenschaft, 2011, p. 275 et seq.

${ }^{119}$ Primarily in the decision on the ,großer Lauschangriff" (BVerfGE 109, 279 et seq.). Further on this Roxin, FS Böttcher, 2007, p. 159 et seq.
} 
Part of the core area of the private lifestyle is doubtlessly the human sexual behaviour to the extent that it takes place outside the public and does not interfere with the right of sexual self-determination of others. It follows from this that homosexual relations among adults and also the incest among siblings may not be punished.

This thought also supports the thesis that it is unconstitutional ${ }^{120}$ to subject the possession of drugs that are solely intended for personal use to punishment as is done by $\S 29$ s. 1 BtMG. For how someone for himself deals with addictive substances (for instance also alcohol and tobacco), is a matter for his very own personal lifestyle and concerns its core area because it is part of his self-realisation. The Argentinian constitutional court thus has, as mentioned, declared the criminally punishable prohibition of drug possession for personal use to be unconstitutional. It found a violation against Art. 19 of the Argentinian constitution, which states that private behaviour is solely God's concern and not that of criminal law. ${ }^{121}$

Greco has recently ${ }^{122}$ developed an "autonomy theoretical rationale" for the constitutional limitation of state penal power and considers that it is "superior to the goods-in-law doctrine". 123 "Respect for the individual's autonomy means that one recognises an area for him on which he alone is entitled to decide. That his consideration largely overlaps with the ... notion of the untouchable core area of the private lifestyle is obvious." 124

What is right about this is that the thesis of the core area explains the unconstitutionality of some cases of criminal provisions without a good-in-law. But this in no way makes the goods-in-law doctrine superfluous. ${ }^{125}$ For firstly, the classification as part of the core area of the private sphere requires the absence of an impairment of goods-in-law of others. Secondly, the unconstitutionality of a penalisation of behaviour that does not impair goods-in-law can also be derived from constitutional principles other than that which warrants the core area, human dignity (namely from the principle of proportionality or specific basic rights). And thirdly, even where the disregard of the goods-in-law principle does not entail unconstitutionality, the principle still has significant importance for legal policy.

A different basic right from whose violation e.g. the unconstitutionality of punishment for "negationism", i. e. the mere non-discriminatory and non-agitative denial of historic facts, can be derived is the freedom of opinion, which consequently Romano ${ }^{126}$, Gimbernat ${ }^{127}$ and the abovementioned Spanish and French constitutional courts expressly invoke.

\footnotetext{
${ }^{120}$ In a current analysis, the same result is reached by Greco, in: Hefendehl (Ed.), Grenzenlose Vorverlagerung des Strafrechts?, 2010, p. 73 et seq.

${ }^{121}$ Also further on this Greco, as fn. 119.

122 Greco, primarily in ZIS 2008, 234 etseq, where he deals with the incest decision by the BVerfG. Cf. on the theses by Greco also Kaspar, as fn. 27, p. 181 et seq.

123 Greco, as fn. 121.

${ }^{124}$ Greco, as fn. 121.

${ }^{125}$ As incidentally also Greco does not suggest (as fn. 121, 238).

${ }^{126}$ Romano, as fn. 6, p. 165.

127 Gimbernat, as fn. 8, 292 et seq.
} 
It thus becomes apparent that in all six cases which I presented above (III, 2, a) as particularly disputed examples for the penalisation of behaviour that does not violate goods-in-law, it is very much possible to explain the unconstitutionality of the relevant provisions. Further examples are provided e.g. by violations against the freedom of religion which may follow from religiously motivated punishment of behaviour that does not impair goods-in-law. An analysis of all criminal provisions whose legitimacy is disputed is not possible here. But Hefendehl ${ }^{128}$ is correct when he says that "the actual development of the goods-in-law theory" even is "yet to come".

${ }^{128}$ Hefendehl, in: Hefendehl/von Hirsch/Wohlers, as fn. 1, p. 290. 